\title{
Social security in Europe. Towards a diachronic perspective for analysing social policy rescaling
}

\author{
Stefanie Börner (stefanie.boerner@paedagogik.uni-halle.de) \\ Martin-Luther-Universität Halle-Wittenberg, Germany \\ Monika Eigmüller (monika.eigmüller@uni-flensburg.de) \\ Europa-Universitaet Flensburg, Germany
}

Keywords: Diachronic comparison, European Union, legitimacy, nation building, rescaling, social policy, solidarity

Recent debates often suggest that welfare states are nation states and that comprehensive social policies at the EU level are therefore inconceivable, given the lack of a European collective identity. Reconsidering former and current periods of social policy rescaling, this paper examines the preconditions for the expansion of the territorial frame of social policy organisation and asks when, why and how actors have been willing to change their frames of action on welfare policies. Adopting a diachronic perspective allows us to examine how processes of re-territorialisation can give rise to new categories of action and reference points which, in turn, establish new types of belonging and solidarity. To this end, we analyse actors' interests, interpretations, motives and discursive shifts. Our findings point to a close intertwining between general structural changes in the economic and political spheres, on the one hand, and the shifting frames of reference and scope of action of the political, collective and individual actors involved, on the other. On the basis of these findings, we argue that structural transformations alter both political discourse and the actors' own interests, which over the long run may lead to the emergence of new actors, ideas and territorial principles. Hence, instead of suggesting the rigid nature of national welfare states and, linked to this, the lack of solidarity at the European level, our historically informed approach sheds light on the creative and conflictive processes that led to the predominance of national social policies.

\section{Introduction}

In view of Europe's ongoing integration and the rising number of transnational social problems it faces in the current crisis, questions regarding the development of the European Union's social dimension are of growing importance. Despite this, many scholars suggest that the lack of a collective identity at the European level, and the absence of transnational solidarities able to transcend the prevailing national solidarities, makes the intensification or broadening of EU-level social policies unlikely in the near future (Streeck 2000; Offe 2003; Scharpf 2010; Höpner/Schäfer 2012). Given this situation, we propose a twofold change in perspective. At the theoretical level, we assume that certain interests and motives of influential actors determine the political processes that could lead such a policy shift (in particular, the growing literature on territorial restructuring provides 
an appropriate framework for this interpretation; cf. Ansell/DiPalma 2004; Moreno/McEwen 2005; Ferrera 2003). At the methodological level, we suggest a diachronic comparison of different periods of social policy rescaling. In reconsidering social policymaking in the past, this article reveals the close intertwining between general structural changes in the economic and political spheres, on the one hand, and political, collective and individual actors' shifting frames of reference and scopes of action, on the other.

Beginning in the 1880s, the emergence of social insurance programmes marked the 'take-off of the modern welfare state' (Flora/Alber 1981: 48). After Germany introduced compulsory health insurance in 1883, an accident insurance scheme in 1884 and a disability and old age insurance in 1889, most Western European countries passed at least one core social insurance law before the outbreak of World War I (Abbott/deViney 1992; Kuhnle/Sander 2010). These contributory or taxfinanced programmes were thought to provide members with a basic income during typical phases of employment incapacity and unemployment.

As public tools for coping with destitution, social insurance programmes were rescaled to ever higher levels during the following decades. This development culminated in the rise of the national welfare state, which extended social insurance to 'increasing numbers of citizens to ever greater varieties of risks' (Baldwin 1990: 1). From that point on, the nation state provided the basic frame of reference for social security organisation. Although the scope of social solidarity was also expanded to the national level with the emergence of social insurance legislation at the central state level, socio-historical research shows that the nationalisation of social security has been anything but uncontroversial (de Swaan, 1988; Baldwin, 1990). Empirical studies suggest that early welfare schemes could not rely on existing collective identities to generate feelings of solidarity at the national level. Rather, the development of national welfare states should be seen as a long-term process linking state-building, identity formation, and solidarity at the national level, i.e., as a process of social security territorialisation (Ferrera 2003; Moreno/McEwen 2005; Börner 2013; Senghaas 2015). Ferrera (2005b: 226) points to the importance of social security schemes for 'creat[ing] new membership spaces within the territory of each nation-state.' During the late 1880s, existing means of social schemes such as locally organised self-help funds, or the support provided by trade unions, were seen as alternative frameworks to that of the nation-state for social security organisation (Zimmermann 2006). This raises a key question: under which conditions have actors been willing to endorse a territorial shift of social policies? Answering this question is crucial to understanding whether solidarity is a result or a precondition of social politics.

Given these highly conflictive processes and their role in constructing the congruence of nations and welfare states, there is no reason to think that the so-called "solidarity among strangers" may only be established within a national framework. To shed light on the preconditions of social policy rescaling, this article examines the conditions under which the territorial frame for social security organisation may be successfully expanded and asks when, why and how actors have been willing to change their frames of action on matters of social policy. In order to illuminate the complex processes that finally led to the nationalisation of social security in Europe, it examines these questions historically. Within the current context of growing (and contested) Europeanisation of social security, this historical analysis gives us the insight to explore how processes of reterritorialisation can create new categories of action and reference points that lead to new types of belonging and solidarity with respect to social policy. As a result, we are able to offer a more comprehensive analysis of recent-and to some degree even future-social policy developments at the European level. 
To fruitfully use historical insights to decode current developments at the EU level, the French sociohistoire ${ }^{1}$ offers a range of concepts and tools for analysing and comparing recent social transformations. Based on the assumption that social phenomena are bound to space and time and hence only comprehensible in terms of the specific historical context in which they are embedded, this approach emphasises the historical emergence of today's macro-categories as well as the microfoundations of social change by identifying the key actors involved, their interests, and their ideas. In this sense, it commits to a theory of action that emphasises the structured activities of those actors and thus overcomes the often-cited micro-macro dichotomy (Knorr-Cetina 1981). This understanding of the variable and constantly changing relationship between structure and action helps illuminate the meaning of transformative processes, deepening our understanding of how specific social problems have been defined and new frames of action have come to prevail (Noiriel 2006). Analysing the specific historical junctures when actions and structure intertwine allows us to compare such junctures across time and place, thus opening the door to diachronic comparison. Key to this diachronic approach is the study of processes as a tool to uncovering the dynamic interplay between actions and structural changes. This requires that we analyse not only structural shifts and institutional changes, but also micro-sociological factors such as the ideas, interests and interpretations of the various actors involved and the specific institutional and organisational contexts in which they were embedded. Focusing on actors' interests, interpretations, motives and discursive shifts makes this micro-macro interplay accessible. Such a focus also allows us to consider European social policy in terms other than the functionalist automatisms and spill-over mechanisms that tend to dominate studies of this subject area (e.g. Leibfried 2005). ${ }^{2}$

In examining the consequences of emergent opportunity structures for different groups of historical actors, this article points to the complex logic and multidimensionality of the processes shaping social policy rescaling. To unravel these interconnected processes of structural change and individuated action, the first part of this article discusses structural transformations, how they translate into ideas, and how they shape individual preferences and political decision-making processes. Parts two and three then present the political logic behind social policy rescaling, which sees the latter as a means of promoting social integration and political legitimation. Evidence is drawn from two centralised Western European welfare states (France and Germany) and two rather plurinational ones (Great Britain and Austria) between the 1880 s and $1914 .{ }^{3}$ For the sake of simplicity, we refer to this period as one of social security nationalisation. ${ }^{4}$ We contrast the results of this analysis with findings from research on the development of EU social policy between the

\footnotetext{
${ }^{1}$ In a close dialogue between history and sociology the Socio-histoire du politique aims at a historical reconstruction of social and political categories such as unemployment (Topalov 1994; Zimmermann 2006) or family (Lénoir 2003) in order to understand and denaturalise the developments of categories of public action that appear to be quite natural today. This consequent sociology of the actors sheds light on forgotten alternatives, conflicts and power constellations that finally led to the studied phenomenon.

${ }^{2}$ Interestingly, the functionalist interpretation of social policy development at nation state level (namely industrialisation, etc. as driving force) had been discarded early. A comparable development that describes EU social policy not only as the result of market compatibility requirements and the like is still in its infancy (see Falkner 1998). ${ }^{3}$ By Austria, we refer to the northern and western part of the Dual Monarchy of Austro-Hungary between 1867 and 1918, so-called Cisleithania. Empirical insights on this case mianly draw on Monika Senghaas' study on social policy in the Habsburg monarchy. (2015) We would like to thank her for allowing us to use her empirical material. 'The term 'nationalisation' should not hide the fact that the resulting welfare states in no way represented a single universal type. Within a given state territory, there remained numerous internal differentiations marking former boundaries (see also FN 7).
} 
1950s and today, a period marked by the Europeanisation of social security. ${ }^{5}$ Thus, instead of comparing different national stories, this study focuses on the diachronic perspective.

Our main goal is to revisit historical processes in order to be able to assess current arguments regarding a European-level social policy. Analysing the shifting interests, strategies and discourse of the actors involved does more, we assume, than simply illuminate the differences between the two periods covered here; it also enhances our understanding of the EU's political construction as a supranational organisation. It explains not only why the EU pursues a rhetoric of cohesion and strives for harmonisation in the field of social security, but also why some of its member states are reluctant to give up their social policy competencies, irrespective of their own abilities to provide social protection. In this way, it helps clarify why European integration is sometimes perceived as a major threat to national solidarity and to existing achievements in the field of social welfare.

\section{Social integration meets economic integration: The territorial dimension of the social question}

In recent decades, the process of European economic integration, which has also helped consolidate political and even social integration at the EU level, has created an awkward structural imbalance in the eyes of many scholars. On the one hand, Europeans have been witnessing the dissolution of nationally-defined boundaries with respect to the EU's economic systems and labour markets. On the other, actual social transfers to individuals as protection against threatening economic developments remain in the hands of the nation state. What is more, this 'structural asymmetry' tends to undermine the social achievements of Europe's most comprehensive and generous welfare states (Scharpf 2010: 211). This challenges social integration at the national level, since entrenched national solidarities are about to break up (Münch 1998). As the EU steadily gains power and national governments are increasingly affected by decisions of the European Court of Justice (ECJ) as well as by regulations of the European Commission (for social policy, see Leibfried/Pierson 1995; Ferrera 2003; Leibfried 2005), member states lose sovereignty.

In the face of these political, economic and social shifts, the preconditions of social integration within a sovereign national framework can no longer be taken for granted. Yet EU social policy is not considered a viable alternative, not only because Europe lacks a collective identity but also because of its missing mandate and fiscal sovereignty, as well as institutional obstacles such as the so-called joint-decision trap. In this context, our study seeks to understand the conditions under which actors will support the rescaling of social policies.

Although it is hard to imagine from today's perspective, considered from a purely politicalinstitutional point of view conditions were no more advantageous during the formative period of national welfare states than they are now. During the nineteenth century, in a number of Western European countries the discrepancy between the economic and social spheres was in many ways at its most extreme. At that point, as during the creation of the European internal market, economic constraints had to give way to more liberal regulations. The dissolution of traditional local economic boundaries since the late eighteenth century has been linked to the abolition of the guild systems, which economic actors increasingly viewed as an impediment to labour mobility. During the

\footnotetext{
${ }^{5}$ Research on EU social policy differs strongly depending on the specific notion of social policy that is used. Widely accepted is the differentiation between regulatory and redistributive social policy (Majone 1996). Meanwhile it seems appropriate to further specify this distinction and to ask how redistributive policy is regulated on the European level by granting specific social rights to Europeans. This is of interest here, since a link between European citizens and the EU has been developing in recent decades. Therefore, the terms 'social policy' and 'social security' are used synonymously in this paper.
} 
nineteenth century, European guild systems gradually lost power and were replaced by free trade laws establishing free markets for labour, capital and goods, introducing free competition and a single currency, standardised weights and measures, and dissolving customs barriers. This process resulted in the existence of parallel but independent protected national economies at the end of the $19^{\text {th }}$ century (Pollard 1981).

With free trade and the abolition of obligatory guilds, a national order of work regulations, labour markets and tariffs emerged. As a consequence, social security schemes mainly organised at the local level-namely, poor relief and mutual benefit societies-could no longer meet the needs of national economies and labour markets and a more mobile labour force. While the new economic order required workers to adapt to cyclical fluctuations, local insurance funds for workers failed to meet this need, as workers risked losing their acquired entitlements whenever they had to leave a specific benefit society. ${ }^{6}$ Thus, in Germany, progressive thinkers such as the social reformer Lujo Brentano (1879) opposed conservative views by proposing a social security system based on existing economic principles, a free and nation-wide insurance scheme that would allow workers to change their occupational location without losing their accumulated insurance contributions.

Also in other European countries, the economic changes that resulted in the establishment of national labour markets within territorial boundaries played a key role in the debates preceding the introduction of social insurance programmes. In contemporary discussions on what came to be known as the social question, the increase in domestic migration resulting from both industrialisation and demographic growth became a salient topic. As such discourse indicates, geographical mobility was perceived as an essential part of the transformation from a rural to an industrial society. Linked to the emergence of nationally organised labour markets was a growing incongruence between the scope of economic and social policies. In Austria, for instance, the free movement of labour was already settled in 1867, even as locally organised poor relief efforts and the small-scale system of mutual benefit societies hampered worker mobility in practice. In order to secure mobility, political elites across all parties pointed out that with an increasingly mobile workforce, the existing social security schemes could no longer provide sufficient coverage (Senghaas 2013: 127-133). In this context, it is not surprising that several deputies stressed the territorial dimension of the social question in their discussion of the government's proposal to create obligatory insurance against work-related accidents in 1886. During that debate, conservative social reformer Aloys von Liechtenstein argued that local social protections only made sense if people worked and died in their place of birth. Under the conditions of regional mobility, with workers moving from the countryside to the growing industrial centres, he declared poor relief to be an 'uninhabitable ruin' (House of Deputies 1886: 2614, own translation).

Members of local or occupational benefit societies were particularly concerned with the free movement of persons within and between these private insurance funds, since this directly affected their well-being. At a central meeting of the benefit societies in Berlin in 1884, for instance, a member of the metal workers' fund aptly remarked that the workers were witnessing a period of centralisation and that therefore the huge number of benefit funds would have to give way to a smaller number of larger funds (QGDS 2009: 375). This was a rather progressive view in comparison to other in-house debates, since most of those who held contemporary benefit funds preferred to maintain the former membership boundaries in order to stay amongst their own kind (Börner 2013). From the very outset, therefore, the perceived incongruence between the scope of social and economic policies impeded successful social integration, to use a recent argument (Bach 2008). The

\footnotetext{
${ }^{6}$ At the micro-level this mobility requirement is reflected by the immense importance of domestic migration at that time. Nearly every second citizen was part of this human flow, either short distance or long distance (Köllmann 1974), both of which could have meant the loss of hard-earned entitlements for sick pay.
} 
suggestion here is that, in the mid-term, the societal imbalances triggered by major economic transformations at the structural level caused a rethinking at the political and individual level. For years and sometimes even for decades, national and municipal authorities, workers, members of benefit societies and social reformers debated the various membership spaces that might serve as alternatives to existing local and occupational schemes. In so doing, they were reacting directly to observed structural changes. This often neglected, territorial dimension of early discussions on social policy is one piece of the puzzle that finally led to the nationalisation of social security.

A similar process can be observed today. However, in contrast to the situation in the late 1800s, public social security has been an established concept for well over a century now, and the social risks are fully covered by state schemes. Thus, even if we now face a territorial reorganisation of market structures in the European Community (institutionalised as the European Single Market ${ }^{7}$ ) similar to that occurring in European nation-states at the end of the $19^{\text {th }}$ century, we lack an idea as revolutionary as that which drove the establishment of a large-scale public social security system during the nationalisation period. What we do find are comparable structural changes and strikingly similar argumentative patterns with respect to the rescaling process. Thus, while supporters of Europeanisation today emphasise the shortcomings of existing closed national schemes, opponents of the idea argue that an opening of national schemes threatens their very existence (e.g. on European healthcare, Obermaier 2009). The European answer to these circumstances is to incrementally align existing social security schemes while gradually enacting a process of territorial expansion by opening today's national systems to all European citizens (Eigmüller 2017). These unintended processes, akin to those taking place during the $19^{\text {th }}$ century, can be partly attributed to the additional mode of territoriality increasing, for example, the cross-border mobility of Europeans. In contrast to the period of social security nationalisation, this process has not been driven by the perception of a de facto requirement-in this case, increasing mobility within the European Community. Rather, it was the ideology of a free common European market and the political idea of a new territorial frame or the European labour market that first triggered the first steps towards EU social policy. For instance, the approximation of social security standards within EU member states has been interpreted as a necessary precondition for the effective implementation of labour mobility policies within the common market. Thus, already in 1968, Regulation No. 1612 enacted by the Council of the EC aimed to secure the free movement of labour:

The freedom of movement for workers should be secured within the Community by the end of the transitional period at the latest; whereas the attainment of this objective entails the abolition of any discrimination based on nationality between workers of the Member States as regards employment, remuneration and other conditions of work and employment, as well as the right of such workers to move freely within the Community in order to pursue activities as employed persons subject to any limitations justified on grounds of public policy, public security or public health (European Council 1968).

These ideas have not always been welcomed among national authorities, as the example of crossborder healthcare shows. Most of the 15 member states vehemently opposed the idea of an EUwide patient mobility, anticipating higher costs and destructive consequences for domestic healthcare and nationally-constituted solidarity mechanisms (see Ferrera 2005a; Obermaier 2009). Despite the fact that the Commission held no competences in this area, questions of cross-border healthcare nevertheless entered the political agenda because they were directly related to the basic principle of free movement. Even if the need to reorganise social security in Europe in response to

\footnotetext{
${ }^{7}$ In order to secure the free movement of goods, capital, services and people, this process, initiated in 1986 through the Single European Act, entails the removal of trade barriers, the approximation of laws and standards, and the equal treatment of all European citizens.
} 
increased worker mobility was already obvious by the 1950s, it took some time to enact these insights into law. This reluctance on the part of the European legislature was the reason why the rulings of the ECJ became the major source of transnational social rights within the EU (Leibfried 2005). Between 1954 and 2001 more than 20\% of all ECJ rulings dealt with social security issues, in cases mainly initiated by individuals claiming their social rights as European citizens and brought to the ECJ via the infringement procedure (ECJ 1997, 2000).

The judiciary's leading position in the process of European social integration is mainly the result of member states' unwillingness to create a common social policy within the EU and their fear of losing competences in this popular policy field. As a consequence, with the exception of some smaller regulatory issues regarding equal treatment, the Commission has thus far lacked a direct mandate for social policy. The piecemeal emergence of a common social policy at the European level can thus be explained by the specific interest constellations and the peculiarities of multi-level-governance, which even gave rise to the $\mathrm{ECJ}$ as a powerful new driving force in the field of social policy. To reframe social security as a national responsibility and reorganise it at the national level was, of course, no easy task. But it was much easier for national governments to react constructively to political pressures during past processes of social policymaking than it is today, given the current situation.

According to the ECJ, legislative responsibility with respect to social issues, in particular meanstested social services, still remains in the hands of the member states. Yet the power to define the content of social rights - that is, the scope of social policies - has gradually been removed from the national context. With regard to the provision of certain social goods, the national territorial principle is currently being overridden by EU citizens who can now request specific social services outside of their member states of residence. At the same time, the pool of persons entitled to social benefits extends far beyond former national borders both financially and legally, given that under certain circumstances even means-tested social services now are allocated according to residency instead of nationality. As a consequence, EU member states are witnessing a process through which boundaries that previously served as essential control features of national welfare regimes are becoming increasingly permeable (Ferrera 2005a; Threlfall 2003). These newly emerging spheres of social entitlement are neither homogeneous nor congruent with each other. Rather, we find a range of partially overlapping territorial and community spheres. The extent to which they diverge from the national situation depends on the field of social policy being governed. In this way, the EU is challenging the basic principle of territoriality among member states as well as a foundational pillar of the national welfare state: the congruence of territory and membership with regard to the granting of comprehensive social rights.

\section{Nation building: Social policy rescaling as source of social integration}

The introduction of national social insurance schemes fundamentally changed the territorial structuring of social security. As the previous section has made clear, the major transformations taking place in social security administration during the late $19^{\text {th }}$ and early $20^{\text {th }}$ centuries were not only the result of the emerging social question (Kaufmann 2003), but also the response to a territorial question. Thus, the final acts establishing mandatory insurance against work accidents, sickness, invalidity and old age put an end to the long debates over the scope of coverage and addressed the needs of all national residents. However, although by the end of this process social security had been tied to the national territory and principles of risk sharing had been established within the national framework, Bismarck-style welfare states were marked by an alternative membership criterion defining access to social security not only in terms of national belonging, but also in terms of functional categories such as productivity. This could not be dismantled overnight. 
Given their strong link to state boundaries and categories of belonging, social programmes have been and still are crucial instruments of social integration and political legitimation. Historically, they helped to establish the boundaries of political communities and to create a network of intimate relations between the population and the state (Banting 1995: 270; Manow 2005; Moreno/McEwen 2005). Therefore, the question of which territorial framework should apply to social security organisation was closely connected to the specific interests of the key actors involved in social policymaking.

While not new information, the fact that political elites were the driving forces behind social reforms in most countries nevertheless draws attention to national authorities' motives in enacting these reforms. Particularly in Germany and Austria, the first states to establish social insurance systems for industrial workers in the 1880s, the main interest of authorities was to stabilise and legitimise the existing political order and to legitimise their governments. In what is probably the best-known example of this, the formation of the German welfare state since the 1880s was 'a large-scale exercise in nation- and state-building' (Manow 2005: 226). On the one hand, it offered the central government a new arena of political activity and a new administrative domain for the state; on the other, it allowed for workers' political participation and social integration into the state. For them, the nation became a key collective point of reference. Political authorities explicitly referred to this welcome side-effect of social policymaking. In November 1881, the "Imperial Address" to the Reichstag, which laid out the principles of the envisioned social security model, stated that it was necessary to improve workers' well-being in order to safeguard domestic peace (QGDS 2003: 6165). Framed as Bonapartist approach, this political strategy can be understood 'as a means used by social elites of preserving the status quo, sidestepping the threat of major reform by granting modest concessions to increasingly important but still largely disenfranchised classes' (Baldwin 1990: 39).

In France, where the development of a public system of social security got a somewhat belated start with the loi sur les retraites ouvrières et paysannes (Workers' and Peasants' Pension Act) of 1910, social integration was also discussed as a major motive behind social policymaking:

The law that we are elaborating on shall be a law of pacification and national unity. [...] This Bill is supposed to establish unity among employer and employee, both with regard to their cooperation and to their mutual feelings of human solidarity. (Débats parlementaires 1905: 1471, own translation)

Also in Austria, where social legislation under the conservative government of Prime Minister Graf von Taaffe closely followed Bismarck's workers insurance schemes, the social rights granted by the state followed the logic of appeasement (Tàlos 1981). By providing workers with state-guaranteed financial benefits during times of unemployment, political authorities not only sought to compensate for missing political rights, but also hoped to strengthen workers' identification with the monarchy (Senghaas 2013). Especially with a view to the EU, the multi-ethnic Austro-Hungarian Empire provides an interesting case. Here, political and social integration through social policy in the field of social insurance administration applied to competing territorial levels. While social security at the sub-state level was thought to strengthen the power of each individual nation, such as Bohemia, welfare provisions at the central-state level were meant to serve as a supranational framework uniting the various different nationalities under a single monarchy (Senghaas 2013: 173197). In the 1886 parliamentary debate over this issue, the German Deputy Karl Lueger, a proponent of centralized regulation, cited the motives laid out by German political elites in the 'Imperial Address' and adapted the latter to the conditions of a multi-national empire:

If these institutions are brought into being, this will evoke in every single citizen, no matter which province he stems from or which language he speaks, the awareness that he belongs to a great and powerful state, a state that protects him and his family, wherever in the empire he 
resides and has founded his family. (House of Deputies 1886: 2534, author's translation)

These controversies between federal and central-state interests reflect the specific politicalgeographical framework of the Austro-Hungarian Empire, which also shaped the resultant social security schemes with respect to administrative tasks and executive rights. This dynamic interplay between different territorial interests in the Austro-Hungarian Empire aptly maps out the areas of tension visible in the European Union today.

In all of these debates, the key actors used categories of collective identity and the solidarity that might follow from it merely as strategic political instruments, a means of altering residents' loyalties and frames of reference. That this was indeed necessary is demonstrated by discussions among benefit society members themselves. When asked whether they were willing to expand their societies' scope of redistribution, British and German workers preferred to stick with the given group: 'When it comes to financial questions fellowship will come to an end here, each profession and each trade association has to take care of themselves' (Shoemakers 1883: 27, own translation), therefore - one could add - '[I]et Cabinet Makers manage their own affairs; - and other trades - Glass Grinders, Mattress Makers, Polishers, etc., etc., manage their own' (Cabinet Makers 1909: 209).

The national experience shows that the political strategy of combining nation building and social policymaking has been rather effective in building a national solidarity over the long term, a result that Paul Pierson has described as 'slow-moving outcome' (Pierson 2003: 189). Yet the effectiveness of this strategy has proven problematic at the European level, where it is still an open question whether social policies created for the supranational context will create an equivalent result, i.e. European solidarity. But while member states' cultural and political legacies make it hard for the EU residents to imagine a European community, it may be argued that the existing EU institutions provide gradually more contact points and opportunities to at least partly shift interests and identities and bring people to endorse social programmes that transcend national boundaries. EU citizens claiming their social rights within the newly formed European judicial arena provide a good example here. Whether as a welfare recipient residing in another EU country, cross-border patient, or foreign student applying for a loan, all claimants presuppose a European social sphere within which they are able to move freely (Eigmüller 2013).

As to when, why and how actors are willing to change their frame of action, this section has discussed the rationale of political actors and EU residents with respect to social policy rescaling. From this perspective, given the divergence of actors' strategic orientations, solidarity must be seen as a result of social policy rather than a requirement for it.

\section{State building: Social policy rescaling as source of political legitimation}

The specific framework chosen for social security organisation is also crucial to issues of legitimation. In a process of 'competitive state building' (Banting 1995), different actors compete with each other for political competences (or try to prevent a loss thereof). ${ }^{8}$ This competition occurs not only between polities at different levels, but also between states and the organisations whose competences the state is trying to assume, as the conflict between British friendly societies and public authorities vividly illustrates.

It comes as no surprise that when the concept of a national obligatory insurance scheme first began

\footnotetext{
${ }^{8}$ However, at the end of the $19^{\text {th }}$ century social policy was a burden for local governments rather than a source of political legitimacy, but this fact even strengthens the argument when considering that sub-state entities only start to expand social policy competencies in situations where they are also trying to promote a process of state building in order to maintain more independent from the central government.
} 
to circulate in Britain at around the turn of the $19^{\text {th }}$ century, and state agency entered a new stage as public authorities gave up their former reluctance to intervene in the social sphere, friendly societies -the British version of mutual benefit societies-vehemently opposed the state plans. Historians agree that British benefit societies formed a powerful opposition to public social legislation and wielded an enormous influence on its final arrangement and implementation (Gilbert 1966; Birke 1983). Without a doubt, obligatory insurance would have been a strong menace to the peace of friendly societies. Hence, their collective efforts aimed to prevent a loss of competences and to maintain their position as a powerful player in the field of health insurance. Their vested interests, the result of a century-long historical accretion, clashed with those of the central state when it started its own campaign for social policy measures and spurred competitive policymaking between private and public interest groups. Convinced that such a scheme would not only provoke a 'crisis in the history of mutual thrift by voluntary effort' but also put an end to their own institutions, friendly societies started a campaign to lobby against the bill. The state programme, they argued, would destroy 'those feelings of benevolence' and 'the warm-hearted, sympathetic visit of the sick steward [would] be replaced by a cold officialism that will only perform so much service for so much monetary consideration [...]' (Oddfellows' Magazine June 1909, cited by Cordery 2003: 165-166). Friendly society officials of the time repeated these arguments like a mantra, showing how much they feared their public competitor. On the other hand, the century-long experience of these groups made them the first point of call for the state when consultations were in order, such that 'the State made the fateful decision of using existing societies to administer the new benefits and of avoiding any direct State administration' (Beveridge 1949: 74). Given their incorporation into the projected national scheme, friendly societies finally came to accept the idea of public insurance as a matter of principle (Gilbert 1966). A comparable process took place in Germany and Austria, where mutual benefit societies were in a much weaker position but elites nevertheless recognised their local and occupational expertise.

Taken together, public endeavours -driven by a wish to strengthen the political legitimacy of the state-provoked fierce opposition from corporate players, who preferred to stick to the status quo and maintain their own position. This conflict-oriented theoretical perspective explains why social policymaking at the European level, which is marked by a steady conflict of interests between the $\mathrm{EU}$ and its member states, is so cumbersome. As during the social security nationalisation process, alternative social policy settings and players in today's EU compete with each other when it comes to questions of sovereignty, membership boundaries or the autonomy of domestic social protection systems (see Falkner 1998; Hantrais 2007).

Official political authorities have found statistics to be an ideal instrument for identifying public problems of national relevance (Kaufmann 2003). Since statistics and their interpretations can shape influential narratives and convey specific visions of society and the state (Overath 2011), the developmental process of modern statehood has been embedded in a process of officialising and collecting individual data. Thus, official statistics have helped to define specific social problems and identify potential solutions (Zimmermann 2006). When Eurostat, the Statistical Office of the European Communities, was founded in 1953, the 'idea to institute a "common statistical language" to compare Europe was born' (European Communities 2003: 5). As the recent example of the (youth) unemployment statistic shows, this idea was very successful in creating a common European benchmark that not only helps to define social problems, but also suggest which problems may be solved at the European level.

Taking a closer look at the latter, the arguments driving the common interest of transferring social policy competences to the European level differ slightly among the actors involved. The European Parliament has largely been in favour of such a transfer. As Hantrais (2007) argues, broadening the 
scope of supranational social policy would enhance the Union's legitimacy and increase solidarity among members of the EU population. Thus, a common EU social policy would strengthen not only the position of the European Parliament as the legitimate democratic representative of the European project, but also of the European project as a whole by increasing the bonds between individual Europeans. This argument in favour of using social policy as a legitimising mechanism has also influenced the European Commission. Thus, in 1993, the former president of the European Commission, Jaques Delors, launched an economic integration project, consisting of the Single European Act and the completion of the common market, to bolster the legitimacy of the 'Social Europe' concept (Delors 1989). Twelve years later, the negative referenda in France and the Netherlands made clear that Europeans are well aware of the democratic and social deficits of the European project. The idea of social policy as a motor of integration and legitimation also seemed to play a key role within individual EU member states at this time, as issues surrounding the EU's social deficit and the Union's exclusive concentration on the neoliberal project of market-building gained prominence in public debates across Europe. A successful implementation of the common market needs a social backing, or so went the constantly repeated argument of the Commission. In the long run, it advised, more competences in the field of social policy would strengthen the position of the European Commission itself. Less idealistic is the ECJ, the most important player in the push to drive social policy up to the European level. Neither for nor against such a transfer of competences, it is mainly interested in upholding the common market programme and protecting the four freedoms, in accordance with its central purpose of ensuring the correct interpretation and application of the treaties establishing the European Communities. To a certain extent this includes establishing common social regulations, as in the case of patient mobility.

Thus, European debates centre on the claim that EU social policy serves as a source of legitimacy that can be used as a basis for future development of the European project. Yet in contrast to national governments, which were and still are trying to vindicate their position - historically with respect to the emerging working class, today with respect to the EU - the European Union struggles to gain political authority from sources formerly under the jurisdiction of national territories. Furthermore, neither the political debates nor the ideas of the European Parliament or Commission can be seen as the actual driving forces behind social policymaking at the European level; ECJ jurisdiction is. Thus, the crucial question today is not whether the idea of input-legitimation will again be used to bring about a rescaling of social policies, but whether the existence of a rescaled, European-level social policy will help to create such a new mode of legitimacy.

\section{Conclusion}

Social policymaking has a long and eventful history of restructuring and reframing, one marked by the constant emergence of new agents, ideas and principles, as well as new social imbalances to be addressed. In contrast to recent discussions highlighting the supposed continuity of national welfare states, we argue for a story of ongoing rescaling and conflictive political negotiation marked by both major changes and incremental shifts. This article has assumed that studying the emergence of national social security systems, one of those transformative historical moments, can broaden our understanding of the current Europeanisation processes taking place in social policy. This approach leads us to a conclusion that contrasts strikingly with the findings of functionalist and institutionalist mainstream literature on EU social politics: namely, that in order to understand social policymaking at the European level we must consider how the actors involved have framed their ideas, interests and strategies to fit with their respective structural and institutional circumstances, and how they invent new techniques and concepts of interpreting social facts that shape the ways problems are tackled. 
Since social policymaking between the 1880s and 1920s was linked to state and nation building, this first discursive shift in response to structural transformations was closely intertwined with the prevalent political rationales of that time. Social policy proved to be a welcome power instrument for enhancing legitimacy and forging social bonds between members of a polity. The European Commission seems to have studied these strategies very carefully, regardless of the distinct historical context from which they developed. Nevertheless, the differences between policymaking then and now become clear when considering the $19^{\text {th }}$ century politics of appeasement. This historical development is without a counterpart today, unless one wants to interpret the EU's Open Method of Coordination as appeasement. In light of the current constellation, the experience of the multinational Austro-Hungarian Empire points to past political strategies for coping with diversity. The UK provides an instructive example of how in such a process of competitive state-building, the parties concerned negotiate to include the previous, non-state actors in the field given their longterm experience with social insurance and in order to break their opposition. In the EU as well, such path-dependent developments result from both strategic political concessions and the desire to make use of existing expert knowledge and structures.

Furthermore, by examining the given frames of national solidarity from a historical perspective we were able to show that the implementation of social policies does not require a collective identity. Transnational structures of social security are in the making even in the absence of solidarity at the EU level-structures that, in the end, also apply to those who opposed opening the boundaries of national schemes. People might strive for congruency between the social order and their group of reference, but categories of belonging are much more flexible and context-sensitive than many scholars assume; that is, they are open to influence from major structural transformations that have been translated into politics. Thus, as European structures emerge people begin referring to these existing institutions and integrating the corresponding opportunity structures into their horizons of action. The identity hypothesis currently prevalent in academic debate fails to address these complex processes.

In sum, rescaling the existing private or local schemes of social security that outlived the $19^{\text {th }}$ century can only be understood in light of a the reterritorialization processes, which made actors change their minds with respect to where social programmes should be organised. Although European actors employ similar arguments, the situation today is even more complex than it was in the past due to the variety of comprehensive state schemes that render a complete transfer of competencies extremely unlikely. Nevertheless, thanks to the EU, territorial (welfare) states have ceased to be 'disjoint, fixed and mutually exclusive' endeavours (Ruggie 1993: 168). The observed processes of re-territorialisation-changing structural constellations, the appearance of new actors, and the alignment of motives and interests-have triggered the development of a European social space that is still incomplete. This new type of territoriality, albeit still under construction, differs from the national one in several respects. The EU must share citizens' loyalties with the member states, which in turn share sovereignty with the Union. Hence, a series of overlapping and non-exclusive membership spaces with respect to social policy is replacing the homogeneous spheres of the past. What is more, the integrative function of social policy at the EU level has only benefited a few mobile Europeans thus far. Finally, the ECJ, one of the major actors in the field, follows a different logic than that of the European Commission, which is much closer to the national governments with respect to its position on social policy. All of this suggests that we are witnessing a major shift into a new kind of European territorialisation.

Highlighting the interpretative patterns and interests of the actors involved allows for a more differentiated understanding of the logic behind EU social policymaking. To access this more 
nuanced understanding it is imperative that we expand our current focus on mainstream functionalist spillover explanations and the identity hypothesis, the latter of which suggests the impossibility of EU-level social policies (Streeck 2000; Scharpf 2010; Offe 2003; Höpner/Schäfer 2012), to include a historically informed, long-term perspective that highlights both the level of action and the political, institutional and economic context factors behind policymaking. Such an approach shows how macro-level structures and institutions shape the interests and opportunities of political, corporate and individual actors, whose actions then shape developments at the structural level. So instead of suggesting the rigid nature of national social security and linked to this the lack of a collective identity at the European level, as has often been discussed during the last years, a historically informed approach sheds light on the creative and conflictive processes that led to the predominance of national social policies in the first place. Such an approach is inevitably selective, but fruitful. It emphasises not only the process-oriented and long-term nature of these processes, but also the constructive power of political boundaries to create social unities. As a consequence, it offers a revised view of nation-wide solidarity as a much more dynamic and contingent institution, one that can also be subject to social change and political negotiation.

\section{References}

Abbott, A., and DeViney, S., (1992). The welfare state as transnational event. Evidence from sequences of policy adoption. Social Science History. 16(2), 245-274.

Bach, M., (2008). Europa ohne Gesellschaft. Politische Soziologie der Europäischen Integration. Wiesbaden: VS Verlag für Sozialwissenschaften.

Baldwin, P., (1990). The Politics of Social Solidarity. Class Bases of the European Welfare State 18751975. Cambridge: Cambridge University Press.

Banting, K.G., (1995). The welfare state as statecraft: Territorial politics and Canadian social policy. Leibfried, S., Pierson, P. (Eds.). European Social Policy: Between Fragmentation and Integration. Washington DC: Brookings, 269-300.

Beveridge, W.H., (1949). Voluntary Action: A Report on Methods of Social Advance. London: Allen \& Unwin.

Birke, A.M., (1983). Soziale Selbsthilfe und amtliche Sozialpolitik im viktorianischen England. Birke, A.M., Kluxen, K. (Eds.). Viktorianisches England in deutscher Perspektive. Munich: Saur. 79-89.

Börner, S., (2013). Belonging, Solidarity and Expansion in Social Policy. Basingstoke: Palgrave Macmillan.

Brentano, L., (1879). Die Arbeiterversicherung gemäss der heutigen Wirtschaftsordnung. Leipzig: Duncker \& Humblot.

Cabinet Makers, (1909). Monthly Reports 1909-1911, MSS.78/CU/4/2/9. Modern Record Centre Warwick.

Cordery, S., (2003). British Friendly Societies, 1750-1914. Basingstoke: Palgrave.

Débats parlementaires, (1905). Annales de la Chambre des Députés. Paris: Imprimerie des Journaux Officiels.

Delors, J., (1989). Speech from Jaques Delors at the European Parliament, January, 17 th 1989. Bulletin der Europäischen Gemeinschaften. Sonderbeilage 6/1989. Luxemburg: Amt für amtliche 
Veröffentlichungen der Europäischen Gemeinschaften.

ECJ, (1997-2000). Court of Justice of the European Union. Annual Reports 1997-2000. Luxembourg: Publications Office of the European Union.

Eigmüller, M., (2013). Europeanization from below. The influence of individual actors on the EU integration of social policies. Journal of European Social Policy. 23(4), 364-376.

Eigmüller, M., (2017). Social Europe still Missing? Flaws of the Spillover Process as the Motor of Integration. Grimmel, A. (Ed.). The Crisis of the European Union: Challenges, Analyses, Solutions. Routledge, 141-156.

European Communities, (2003). 50 Years of Figures on Europe. Data 1952-2001. Luxembourg: Publications Office of the European Union.

European Council, (1968). Regulation (EEC) No 1612/68 of the Council of 15 October 1968 on freedom of movement for workers within the Community. Official Journal L 257. 2-12.

Falkner, G., (1998). EU Social Policy in the 1990s: Towards a Corporatist Policy Community. London/ New York: Routledge.

Ferrera, M., (2003). European integration and national social citizenship: Changing boundaries, new structuring? Comparative Political Studies. 36(6), 611-652.

Ferrera, M., (2005a). The Boundaries of Welfare. European Integration and the New Spatial Politics of Social Protection. Oxford: Oxford University Press.

Ferrera, M., (2005b). Beyond national social rights? McEwen, N., Moreno, L. (Eds.). The Territorial Politics of Welfare. London: Routledge. 225-243.

Flora, P., Alber, J., (1981). Modernization, Democratization, and the Development of Welfare States in Western Europe. Flora, P., Heidenheimer, A.J. (Eds.). The Development of Welfare States in Europe and America. New Brunswick/London: Transaction Publishers. 37-80.

Gilbert, B.B., (1966). The Evolution of National Insurance in Great Britain: The Origins of the Welfare State. London: Joseph.

Glinos, I.A., Baeten, R., (2006). A Literature Review of Cross-border Patient Mobility in the European Union. Brussels: Observatoire Social Européen.

Hantrais, L., (2007). Social Policy in the European Union (3rd edn). Basingstoke: Palgrave.

Höpner, M., Schäfer, A., (2012). Embeddedness and Regional Integration: Waiting for Polanyi in a Hayekian Setting. International Organization. 66(3): 429-455.

House of Deputies, (1986). Stenographische Protokolle über die Sitzungen des Hauses der Abgeordneten des österreichischen Reichsrates. Wien: K.K. Hof- und Staatsdruckerei, Sessions 9 to 21.

Kaufmann, F.X., (2003). Varianten des Wohlfahrtsstaats. Der deutsche Sozialstaat im internationalen Vergleich. Frankfurt/Main: Suhrkamp.

Köllmann, W., (1974). Bevölkerung in der industriellen Revolution. Studien zur Bevölkerungsgeschichte Deutschlands. Göttingen: Vandenhoeck \& Ruprecht.

Kuhnle, S., Sander, A., (2010). The emergence of the welfare state. Castles, F.G. et al. (Eds.). The Oxford Handbook of Welfare State. Oxford: Oxford University Press. 61-80.

Leibfried, S., (2005). Social policy: Left to the judges and the markets? Wallace, W., Wallace, H., Pollack, M.A. (Eds.). Policy-Making within the European Union (5th edn). Oxford: Oxford University 
Press. 243-278.

Leibfried, S., Pierson, P. (Eds.), (1995). Semisovereign welfare states: Social policy in a multitiered Europe. European Social Policy:Between Fragmentation and Integration. Washington: The Brookings Institution. 43-77.

Lénoir, R., (2003). Généalogie de la morale familiale. Paris: Editions du Seuil.

Manow, P., (2005). Co-operative federalism and the overgrazing of the fiscal commons. Obinger, H., Leibfried, S., Castles, F.G., (Eds.). Federalism and the Welfare State. New World and European Experiences. Cambridge: Cambridge University Press. 222-262.

Moreno, L., McEwen, N. (Eds.), (2005). Exploring the territorial politics of welfare. The Territorial Politics of Welfare. Oxon/New York: Routledge. 1-40.

Münch, R., (1998). Globale Dynamik, lokale Lebenswelten: Der schwierige Weg in die Weltgesellschaft. Frankfurt/Main: Suhrkamp.

Noiriel, G., (2006). Introduction à la socio-histoire. Paris: Découverte.

Obermaier, A.J., (2009). The End of Territoriality? The Impact of ECJ Rulings on British, German and French Social Policy. Farnham: Ashgate.

Offe, C., (2003). The European model of "social" capitalism: Can it survive European integration? The Journal of Political Philosophy. 11(4), 437-469.

Overath, P. (Ed.), (2011). Einleitung. Die vergangene Zukunft Europas. Bevölkerungsforschung und prognosen im 20. und 21. Jahrhundert. Köln: Böhlau. 7-26.

Pollard, S., (1981). The Integration of the European Economy Since 1815. London: Allen \& Unwin.

QGDS, (2003). Quellensammlung zur Geschichte der deutschen Sozialpolitik 1867 bis 1914. II. Abteilung, 1. Band: Grundfragen der Sozialpolitik. Ed. by Ayaß, W., Tennstedt, F., Winter, H., Darmstadt: WBG.

QGDS, (2009). Quellensammlung zur Geschichte der deutschen Sozialpolitik 1867 bis 1914. II. Abteilung, 5. Band: Die Gesetzliche Krankenversicherung und die eingeschriebenen Hilfskassen. Ed. by Hänlein, A., Tennstedt, F., Winter, H., Darmstadt: WBG.

Ruggie, J.G., (1993). Territoriality and Beyond: Problematizing Modernity in International Relations. International Organization. 47(1), 139-174.

Scharpf, F.W., (2010). The Asymmetry of European Integration, or: Why the EU Cannot Be a 'Social Market Economy'. Socio-Economic Revue. 8(2), 211-250.

Senghaas, M., (2015). Die Territorialisierung sozialer Sicherung. Raum, Identität und Sozialpolitik in der Habsburgermonarchie. Wiesbaden: Springer VS.

Shoemakers, (1883). Protokoll-Bericht der 5. ordentlichen Gerneralversammlung des Gewerkvereins der Deutschen Schuhmacher und Lederarbeiter sowie der 3. ordentlichen Generalversammlung der Eingeschriebenen Hülfskasse. Berlin: Bertinetti.

Streeck, W., (2000). Competitive solidarity: Rethinking the "European Social Model". Offe, C. (Ed.). Kontingenz und Krise. Institutionenpolitik in kapitalistischen und postsozialistischen Gesellschaften. Frankfurt/Main: Campus. 245-261.

de Swaan, A., (1988). In Care of the State: Health Care, Education, and Welfare in Europe and the USA in the Modern Era. New York: Oxford University Press.

Tàlos, E., (1981). Staatliche Sozialpolitik in Österreich. Rekonstruktion und Analyse. Wien: Verlag für 
Gesellschaftskritik.

Threlfall, M., (2003). European social integration: Harmonisation, convergence and single social areas. Journal of European Social Policy. 13(2), 121-139.

Topalov, C., (1994). La naissance du chômeur, 1880-1910. Paris: Albin Michel.

Zimmermann, B., (2006). Arbeitslosigkeit in Deutschland: Zur Entstehung einer sozialen Kategorie. Frankfurt/Main: Campus. 